\title{
Rheumatoid arthritis and myasthenia gravis: a case-based review of the therapeutic options
}

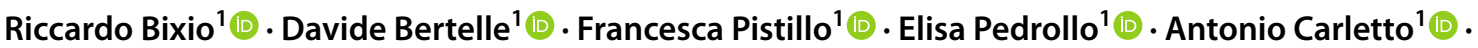 \\ Maurizio Rossini ${ }^{1}\left[\right.$. Ombretta Viapiana ${ }^{1}[0$
}

Received: 18 November 2021 / Revised: 8 January 2022 / Accepted: 10 January 2022 / Published online: 14 January 2022

(C) The Author(s) 2022

\begin{abstract}
Introduction Myasthenia gravis is an autoimmune disease affecting the neuromuscular junction, often associated with other autoimmune diseases, including rheumatoid arthritis. Patients with rheumatoid arthritis present an increased prevalence of myasthenia gravis compared to the general population. While these two diseases share some therapeutic options, such as glucocorticoids, methotrexate, and rituximab, there are no guidelines for treating concomitant disease. We aim to review the available evidence and to discuss the efficacy and safety of the therapeutic options in patients with rheumatoid arthritis associated with myasthenia gravis.

Method We described three patients with rheumatoid arthritis associated with myasthenia gravis and we performed a systematic review of the associated literature.

Results A 48-year-old man and two women (48 and 55 years old) with concomitant diagnoses of active rheumatoid arthritis and well-controlled myasthenia gravis are described. They were treated with methotrexate, leflunomide, upadacitinib, and adalimumab. None of them experienced changes in their myasthenic symptoms. We found 9 additional cases from our literature review. Methotrexate, rituximab, upadacitinib, diphenyl sulfone, auranofin, and loxoprofen sodium did not show an impact on the seven patients with previously well-controlled myasthenia. Glucocorticoids, methotrexate, and rituximab proved effective in active myasthenia gravis and arthritis. Conflicting data emerged for Tumor-necrosis factor inhibitors.

Conclusions Although the available evidence remains scarce, we consider glucocorticoids, methotrexate, and rituximab as safe and effective options. The role of tumor-necrosis factor inhibitors remains uncertain. Eventually, Janus Kinase inhibitors are a novel interesting option for these patients.

Key Points

- To date, the only evidence on the treatment of patients with rheumatoid arthritis and concomitant myasthenia gravis derives from case reports.

- Based on the review of the available case reports and on the cases we described, we consider glucocorticoids, methotrexate, and rituximab as safe and effective options, while the role of Tumor-necrosis factor inhibitors remains uncertain.

- Based on the cases we described, Janus Kinase inhibitors are a novel interesting option for patients with concomitant rheumatoid arthritis and myasthenia gravis.
\end{abstract}

Keywords Rheumatoid arthritis $\cdot$ Myasthenia gravis $\cdot$ bDMARDs $\cdot$ tsDMARDs $\cdot$ JAK inhibitors

Riccardo Bixio

dott.riccardobixio@gmail.com

Davide Bertelle

davide.bertelle@gmail.com

Francesca Pistillo

pistillo.f@hotmail.it

Elisa Pedrollo

elisa.pedrollo@gmail.com
Antonio Carletto

antonio.carletto@aovr.veneto.it

Maurizio Rossini

maurizio.rossini@univr.it

Ombretta Viapiana

ombretta.viapiana@univr.it

1 Rheumatology Section, Department of Medicine, University of Verona Hospital Trust, 37134 Verona, Italy 


\section{Introduction}

Myasthenia gravis (MG) is a rare (prevalence of 150-250 cases per million) antibody-mediated autoimmune neuromuscular disorder, characterized by weakness of eye muscles alone (ocular MG) or alongside skeletal muscles (generalized MG). The disease pathogenesis has been well characterized and three main autoantibodies have been described: antibodies against the acetylcholine (ACh) receptor (AChR) (80\%), antibodies against muscle-specific kinase (MuSK), and antibodies against lipoprotein-receptor-related protein 4 (LRP4) [1]. MG patients present an increased frequency of a second autoimmune disease (around 13-22\%), the most common being autoimmune thyroiditis (10-12\%), followed by systemic lupus erythematosus $(1-8 \%)[2,3]$. Thymectomy was associated with an increased risk of developing a second autoimmune disease in patients with MG (OR 4.4) [3], suggesting a possible underlying defect in autoreactive clones deletion [4]. The frequency of rheumatoid arthritis (RA) in patients with MG is estimated between 1-4\% [5, 6]. A meta-analysis estimated a $3 \%$ prevalence of associated conditions [7]. Small populations of patients with MG reported similar values [2, 8]. On the other hand, patients with RA present an increased prevalence of MG compared to the general population (84/100.000 versus 35.8/100.000) [9]. The therapeutic options in MG range from acetylcholine esterase inhibitors (AchEi) (e.g., pyridostigmine) to traditional immunosuppressive drugs (e.g., glucocorticoids (GC), azathioprine, cyclosporine, mycophenolate mofetil, methotrexate (MTX), cyclophosphamide, and tacrolimus), short term treatments for the acute disease management as intravenous immunoglobulins (IVIG), plasma exchange (PLEX), and novel biologic therapies (rituximab, eculizumab) $[10,11]$. These drugs only partially overlap with the treatments approved for RA, some of them, as D-penycillamine [12] and some Tumor Necrosis Factor inhibitors (TNFi) [13] have been correlated to MG development.

In this paper, we aim to discuss the therapeutic options for rheumatologists treating patients with RA associated with MG. We focused on therapies approved for RA, performing a literature review of cases of patients with RA and MG, to assess the impact of antirheumatic treatment on MG. We also described three patients with RA and MG, two of them treated with upadacitinib, a Janus Kinase inhibitor (JAKi) approved for RA, [14] and one patient treated with adalimumab (ADA).

\section{Methods}

We described three patients' clinical, laboratory, and therapeutic medical history based on their medical records. We collected the following data: gender, age, clinical course,
C-reactive protein (CRP) level, Disease Activity Score-28 based on CRP (DAS28-CRP), pharmacological history, and outcome. Then, we performed a systematic review of the literature for therapeutic options in patients with MG and RA following the Preferred Reporting Items for Systematic Reviews and Meta-Analyses (PRISMA) guidelines. The inclusion criteria for articles were (1) article published from 1998 (approval date of infliximab, the first bDMARD used in rheumatology) [15] to October 2021, (2) article written in English, (3) full article available, and (4) complete diagnostic and therapeutic patient data available in the article. We explored the MEDLINE/Pubmed database on 1st of November 2021, using the following queries: (rheumatoid arthritis[Title]) AND (myasthenia gravis[Title]); (drug name[Title]) AND (myasthenia gravis[Title]). The article search flowchart is shown in Fig. 1, and the complete list of drug names searched for with correlated results are listed in Table 1. We screened the title and abstract of the retrieved work before inclusion to assess relevance. We checked the references of the retrieved articles to evaluate further reports. We checked and removed the duplicate results. Then, we read carefully through the full articles to include the reported cases in our review. All retrieved entries were independently reviewed by two different authors (RB and DB). We included a summary of their clinical and therapeutic history in Table 2. For classification of MG disease activity, severity, and response to therapy, we used the myasthenia gravis recommendations for clinical research standards of the Task Force of the Medical Scientific Advisory Board of the Myasthenia Gravis Foundation of America [16], taking into account the updates from the most recent International Consensus proposals [11]. For RA, we used the American College of Rheumatology and the European League against Rheumatism definitions [17, 18].

\section{Results}

\section{Our cases' descriptions}

\section{Patient 1}

A 48-year-old man was diagnosed with seropositive nonerosive RA (anti-citrullinated protein antibodies (ACPA) and rheumatoid factor (RF)) in 2012 after developing arthralgia and symmetrical and bilateral swelling of the small joints of the hands and of the wrists. He also presented a history of autoimmune thyroiditis. He received treatment with Methotrexate from 2012, initially at the dose of $15 \mathrm{mg} /$ week, then reduced to $10 \mathrm{mg} /$ week after showing gastrointestinal intolerance, while remaining in remission. In 2019 he developed generalized MG with palpebral ptosis and muscle weakness, with positive AChR antibodies ( $92 \mathrm{nmol} / \mathrm{L}$ ) and negative 
Fig. 1 The article search flowchart

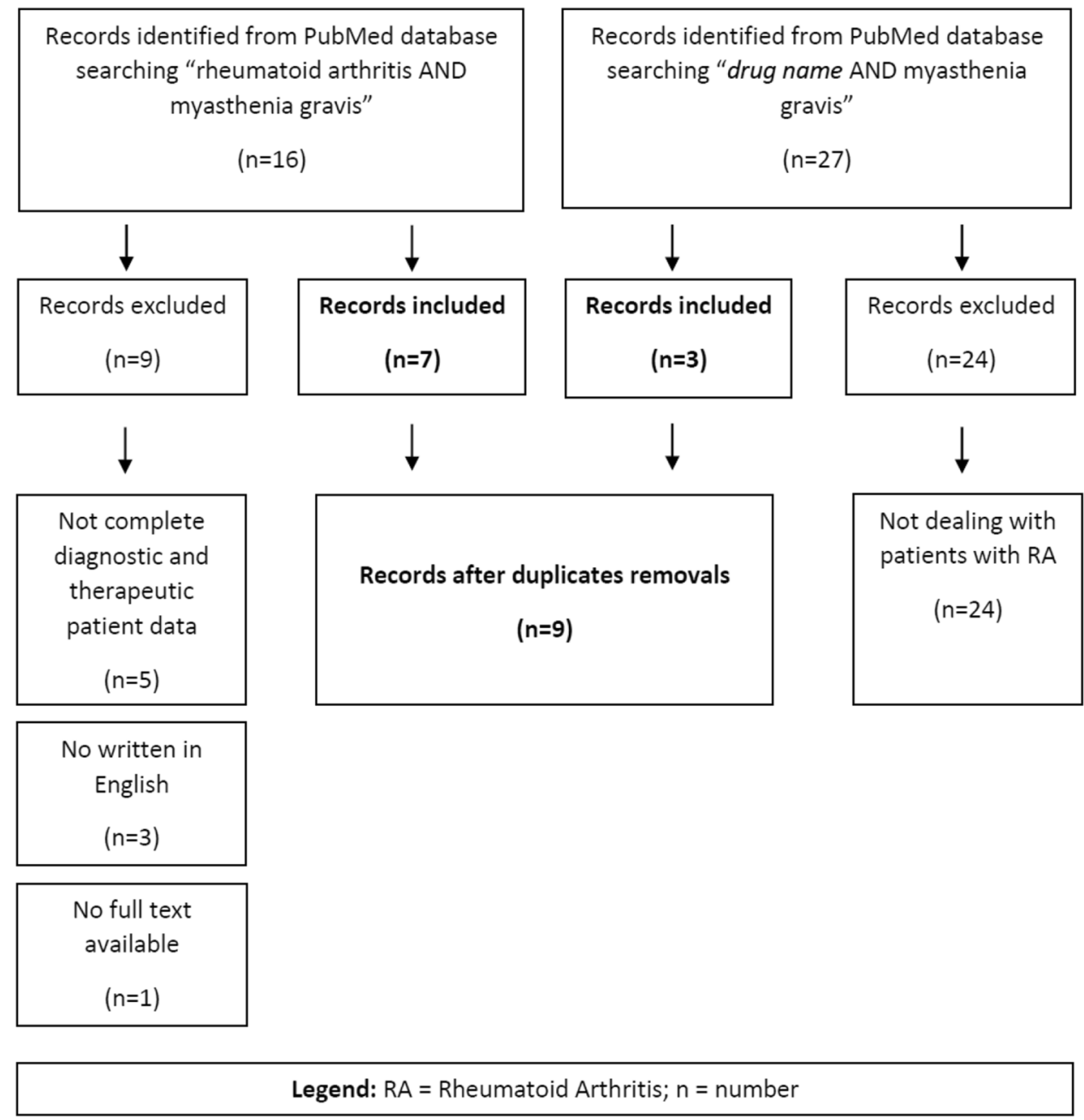

anti-MusK antibodies. A computed tomography (CT) scan showed thymic hyperplasia, therefore thymectomy was performed later that year. MTX was temporarily halted. He received pyridostigmine (60 $\mathrm{mg} /$ three times daily (TID)), with minimal manifestations on AchEi (MM-2). In May 2020, there was a relapse of RA; MTX was resumed, but without relevant impact on disease activity. In April 2021, the patient DAS28-CRP was 4.82 (moderate disease activity), and it was therefore decided to begin treatment with Upadacitinib in association with MTX. After 1 month of follow-up, the patient reported a $60 \%$ improvement in pain and swelling (DAS28-CRP 2.74-low disease activity). After 4 months of follow-up, the patient RA was in remission (DAS28-CRP 1.65). During all this period, the patient did not require any change in the dose of pyridostigmine for MG.

\section{Patient 2}

A 55-year-old woman had a diagnosis of erosive seropositive $(\mathrm{ACPA}+, \mathrm{RF}-) \mathrm{RA}$ in 1991 with the involvement of wrists and hands joints. She was initially treated with sulfasalazine, then associated with MTX until January 2017. Because of gastrointestinal intolerance to MTX, she was then treated with leflunomide only, remaining in low disease activity. In 2008, she presented palpebral ptosis, diplopia, and generalized muscle weakness, leading to diagnosing MG. Thymectomy was performed in the same year, no immunosuppressive treatment was started, and she controlled her mild symptoms with pyridostigmine only (current dose $105 \mathrm{mg}$ / day) (MM-2). In June 2021, she manifested an active RA (DAS28-CRP 3.45) confirmed by hand ultrasound, which showed active tenosynovitis at multiple locations. Given the disease activity and the erosive nature of her RA, Upadacitinib $15 \mathrm{mg} /$ day was started. After 3 months of therapy with UPA, RA was in remission (DAS28-CRP 1.64), as confirmed by hand ultrasound, and the neurological examination did not show any change in MG.

\section{Patient 3}

A 48-year-old woman presented to our outpatient clinic in June 2015 with arthralgia of hands and feet. Her blood exams 
Table 1 Drugs name searching terms: list and results

\begin{tabular}{lll}
\hline & Retrieved papers & $\begin{array}{l}\text { Patients } \\
\text { with } \\
\text { RA }\end{array}$ \\
\hline Methotrexate & 13 & 0 \\
Leflunomide & 4 & 0 \\
Tumor necrosis factor inhibitors & 1 & 1 \\
Adalimumab & 0 & 0 \\
Certolizumab & 1 & 1 \\
Etanercept & 0 & 0 \\
Golimumab & 0 & 1 \\
Infliximab & 0 & 0 \\
Sarilumab & 1 & 0 \\
Tocilizumab & 1 & 0 \\
Abatacept & 1 & 0 \\
Janus Kinase Inhibitors & 0 & 0 \\
Baricitinib & 0 & 0 \\
Tofacitinib & 0 & 0 \\
Upadacitinib & 0 & 0 \\
Abatacept & 1 & 0 \\
\hline
\end{tabular}

$R A$, rheumatoid arthritis

showed positivity of ACPA (117.9 CU), RF (38 KU/L), antinuclear antibodies (1:320), and anti-SSA antibodies. She had an increased erythrocyte sedimentation rate (44 mm/hour) and CRP (17 mg/L). Hand ultrasound showed active tenosynovitis without erosive damage. A diagnosis of RA was made, and she was initially treated with a low dose of GC (Prednisolone (PDN) $7.5 \mathrm{mg} /$ day) and HCQ. In 2017, after a RA flare (CRP $15 \mathrm{mg} / \mathrm{L}$ ), we decided to treat her with Certolizumab Pegol, associated with low doses of GC (PDN $2.5 \mathrm{mg} /$ day). The patient had received a previous diagnosis of myasthenia gravis in 2000, with initial presentation of palpebral ptosis and diplopia, and positive anti-AchR antibodies ( $10 \mathrm{nmol} / \mathrm{L})$. The $\mathrm{MG}$ was initially treated with high doses of GC and azathioprine, and after the initial remission, she was treated with Pyridostigmine only. In 2003, a CT scan revealed thymic hyperplasia and thymectomy was performed. An exacerbation of her MG occurred in 2008, and an IVIG cycle was administered with remission of the symptoms, controlled with a low dose of pyridostigmine (MM-2). From the diagnosis of RA to September 2021, her neurologic examinations did not show any changes in her MG disease activity (MM2). At her last rheumatologic examination in October 2021, she was in remission (DAS28-CRP 1.99).

\section{Literature review}

We retrieved 9 case reports of patients with concomitant RA and MG [19-27] and described three more cases. The clinical and therapeutic characteristics are summarized in
Table 2. Six patients had active MG at a certain point of their history: three patients developed myasthenia gravis during treatment with TNFi (etanercept (ETN) $n=2$, adalimumab (ADA) $n=1$ ) alone or with MTX (2/3), one had an exacerbation of MG after the suspension of azathioprine and ADA for pneumonia, and one patient developed acute RA and MG at the same time. Between the six patients with active MG, two were successfully treated with RTX, one with GC only and one patient ameliorated MG symptoms after ETN suspension. For two patients, no details are provided. Nine patients were already affected by myasthenia gravis when the antirheumatic treatment was started. The following drugs did not show an impact on the seven patients with previously well-controlled MG (minimal manifestations with AchEi only (MM-2) $n=5$, minimal manifestation without therapy (MM-0) $n=1$, pharmacologic remission $(\mathrm{PR}) n=1)$ : methotrexate $(n=4)$, upadacitinib $(n=2)$, TNFi (ADA $n=1$, Certolizumab pegol $n=1$ ), diphenyl sulfone, auranofin, loxoprofen sodium $(n=1)$ (total greater than 7 because some patients were on combination therapy). There was great variability in follow-up ranging from a few days after the initial antirheumatic treatment to several years after its beginning. We did not retrieve any randomized controlled trial or metaanalysis or expert opinion article about our research topic.

\section{Discussion}

Reports of patients with concomitant RA and MG are scarce in the literature, but additional information could be extrapolated by patients with MG treated with drugs approved as antirheumatic drugs. Methotrexate, the anchor drug for RA, although did not show efficacy on MG [28], is nonetheless suggested as a possible steroid-sparing agent in refractory MG [10], and our finding does not contraindicate its use. Our review illustrated two cases of rituximab effectiveness in concomitant RA and MG, coherently with existing recommendations for both diseases [10, 29]. We found conflicting evidence about TNFi: while some reports suggest etanercept could be effective in reducing MG symptoms in some patients [30], others associated the treatment with TNFi with symptoms worsening or MG development in patients treated with TNFi for RA and Psoriatic arthritis (PsA) [24, 25, 31, 32]. Tocilizumab, an interleukin- 6 inhibitor, has been used with success in two patients with MG refractory to RTX [33]. Abatacept, a recombinant Cytotoxic T-Lymphocyte Antigen 4 (CTLA4) fusion molecule used in RA, has been reported as effective in a Nivolumab-induced $\mathrm{MG}$ in an oncologic patient [34]. Interestingly, the anti-CTLA 4 checkpoint inhibitor ipilimumab, used for melanomatous skin cancer, has been linked to MG development or worsening [35].

One of the novelties of our case reports is the utilization of JAKi (upadacitinib) in patients with pre-existent MG. 
Table 2 Demographical, clinical, and therapeutic characteristics of the patients with rheumatoid arthritis and myasthenia gravis

\begin{tabular}{|c|c|c|c|c|c|c|}
\hline & Age (yrs) & Sex & Myasthenia gravis & Rheumatoid arthritis & Antirheumatic therapies & Clinical course \\
\hline Oono et al., 2018 [20] & 36 & $\mathrm{~F}$ & $\begin{array}{l}\text { Generalized, thymectomy, } \\
\text { seropositivity not speci- } \\
\text { fied, } \\
\text { MM-2 }\end{array}$ & $\begin{array}{l}\text { Seropositivity not speci- } \\
\text { fied } \\
\text { Remission }\end{array}$ & MTX, GC & $\begin{array}{l}\text { No impact on MG was } \\
\text { reported } \\
\text { Comorbidity: rheumatoid } \\
\text { meningitis (managed with } \\
\text { GC increase) }\end{array}$ \\
\hline $\begin{array}{l}\text { Novella-Navarro et al., } \\
2018 \text { [21] }\end{array}$ & 66 & $\mathrm{~F}$ & $\begin{array}{l}\text { ocular, } \\
\text { anti AchR+, } \\
\text { new-onset }\end{array}$ & $\begin{array}{l}\mathrm{ACPA}+, \mathrm{RF}+ \\
\text { Remission }\end{array}$ & MTX, ETN, RTX & $\begin{array}{l}\text { MG onset after } 6 \text { weeks of } \\
\text { ETN and } 23 \text { months of } \\
\text { MTX. RTX (1000 mg, } \\
\text { then } 500 \mathrm{mg} \text { every } \\
6 \text { months) led to the remis- } \\
\text { sion of both MG and RA }\end{array}$ \\
\hline Angelucci et al., 2010 [19] & 68 & $\mathrm{~F}$ & $\begin{array}{l}\text { Seropositivity not speci- } \\
\text { fied, } \\
\text { PR }\end{array}$ & $\begin{array}{l}\text { Seropositivity not speci- } \\
\quad \text { fied } \\
\text { Remission }\end{array}$ & $\mathrm{GC}, \mathrm{AZA}, \mathrm{ADA}$ & $\begin{array}{l}\text { No impact on MG was } \\
\text { reported. Exacerbation of } \\
\text { MG after antirheumatic } \\
\text { drugs withdrawal for } \\
\text { pneumonia } \\
\text { Comorbidity: Crohn's } \\
\text { disease, Uveitis }\end{array}$ \\
\hline Horai et al., 2014 [22] & 73 & M & $\begin{array}{l}\text { Manifestation not speci- } \\
\text { fied, } \\
\text { seropositivity not speci- } \\
\text { fied, } \\
\text { MM-2 }\end{array}$ & $\begin{array}{l}\mathrm{ACPA}+ \\
\text { new-onset }\end{array}$ & MTX, GC & $\begin{array}{l}\text { No impact on MG was } \\
\text { reported }\end{array}$ \\
\hline Kerkeni et al., 2008 [23] & 50 & $\mathrm{~F}$ & $\begin{array}{l}\text { Generalized, } \\
\text { anti-AchR +, new-onset }\end{array}$ & $\begin{array}{l}\text { Seronegative } \\
\text { active }\end{array}$ & $\begin{array}{l}\text { GC, MTX, AZA, IVIG, } \\
\text { PEEX, } \\
\text { RTX }\end{array}$ & $\begin{array}{l}\text { New-onset of MG and active } \\
\text { RA, therapy with AZA, } \\
\text { IVIG, and PEEX ineffec- } \\
\text { tive; RTX ( } 375 \mathrm{mg} / \mathrm{m}^{2} \\
\text { weekly over } 4 \text { weeks) led } \\
\text { to remission of both MG } \\
\text { and RA }\end{array}$ \\
\hline Pelachas et al., 2020 [24] & 42 & $\mathrm{~F}$ & $\begin{array}{l}\text { Ocular, } \\
\text { seronegative, } \\
\text { new-onset }\end{array}$ & $\begin{array}{l}\mathrm{RF}+, \\
\text { remission }\end{array}$ & MTX, ADA & $\begin{array}{l}\text { MG onset after } 18 \text { months } \\
\text { of ADA and } 24 \text { months } \\
\text { of MTX }\end{array}$ \\
\hline Fee et al., 2009 [25] & 66 & M & $\begin{array}{l}\text { Generalized, anti-AchR }+ \text {, } \\
\text { new-onset }\end{array}$ & $\begin{array}{l}\mathrm{RF}-\text { no additional infor- } \\
\text { mation }\end{array}$ & ETN & $\begin{array}{l}\text { MG onset after } 6 \text { yrs of } \\
\text { ETN, resolution after } \\
\text { suspension }\end{array}$ \\
\hline Wakata et al., 2001 [26] & 56 & $\mathrm{~F}$ & $\begin{array}{l}\text { Generalized, } \\
\text { thymectomy, } \\
\text { anti-AchR+, } \\
\text { MM-0 }\end{array}$ & $\begin{array}{l}\mathrm{RF}+ \\
\text { new-onset }\end{array}$ & $\begin{array}{l}\text { Diphenyl sulfone } \\
\text { auranofin } \\
\text { loxoprofen sodium }\end{array}$ & $\begin{array}{l}\text { Resolution of RA, no impact } \\
\text { on MG was reported }\end{array}$ \\
\hline Zis et al., 2014 & 69 & M & $\begin{array}{l}\text { Generalized anti-AchR }+ \text {, } \\
\text { new-onset }\end{array}$ & $\begin{array}{l}\text { ACPA+, } \\
\text { new-onset }\end{array}$ & GC & $\begin{array}{l}\text { Simultaneous onset of MG } \\
\text { and RA, GC ( } 75 \mathrm{mg} / \text { day) } \\
\text { treatment led to remission } \\
\text { of both }\end{array}$ \\
\hline Described case 1 & 48 & $\mathrm{M}$ & $\begin{array}{l}\text { Generalized anti-AchR }+ \text {, } \\
\text { MM-2 }\end{array}$ & $\begin{array}{l}\mathrm{ACPA}+, \mathrm{RF}+ \\
\text { active }\end{array}$ & MTX, UPA & $\begin{array}{l}\text { UPA and MTX led to } \\
\text { remission of RA, with no } \\
\text { impact on MG }\end{array}$ \\
\hline Described case 2 & 55 & $\mathrm{~F}$ & $\begin{array}{l}\text { Generalized } \\
\text { anti-AchR + } \\
\text { MM-2 }\end{array}$ & $\begin{array}{l}\mathrm{ACPA}+, \mathrm{RF}- \\
\text { active }\end{array}$ & LEF, UPA & $\begin{array}{l}\text { UPA and LEF led remission } \\
\text { of RA, with no impact } \\
\text { on MG }\end{array}$ \\
\hline Described case 3 & 54 & $\mathrm{~F}$ & $\begin{array}{l}\text { Generalized, anti-AchR }+ \text {, } \\
\text { MM-2 }\end{array}$ & $\mathrm{ACPA}+, \mathrm{RF}+$ active & GC, HCQ, CTZ-peg & $\begin{array}{l}\text { CTZ-peg led to remission } \\
\text { of RA, with no impact } \\
\text { on MG }\end{array}$ \\
\hline
\end{tabular}

$A C P A$, anti-citrullinated peptide antibodies; ADA, adalimumab; Anti-AchR, anti-acetylcholine receptor antibodies; AZA, azathioprine; CTZ-peg, certolizumab pegol; ETN, etanercept; $F U$, follow-up; $G C s$, glucocorticosteroids; $H C Q$, hydroxychloroquine; $I V I G$, intravenous immunoglobulin; $L E F$, leflunomide; $M G$, myasthenia gravis; $M M-0$, no MG treatment received for at least 1 year; $M M-2$, minimal manifestations (only low dose cholinesterase inhibitors); $M T X$, methotrexate; $P E E X$, plasma-eritroexchange; $P R$, pharmacologic remission; $R A$, rheumatoid arthritis; $R F$, rheumatoid factor; $R M$, rheumatoid meningitis; $R T X$, rituximab; $U P A$, upadacitinib; yrs, years

To our knowledge, there is only one patient with active MG previously treated with another JAKi (ruxolitinib) for his myelodysplastic syndrome, with amelioration of both diseases [36]. Ruxolitinib, which is used to treat myelofibrosis, polycythemia vera, and graft versus host disease [37, 38], is not approved in Europe and the USA for RA. 
Alboini et al. reported that the patient's acute MG went into remission after starting the treatment with ruxolitinib, even if the causal effect is difficult to assess since MG is a disease characterized by fluctuating disease activity and spontaneous remissions are possible [36]. Our patients had a wellcontrolled MG (MM-2) at the beginning of the new antirheumatic treatment; therefore, we could not bring further evidence about their efficacy on MG; however, we did not observe a worsening of their MG during follow-up. JAKi are known to reduce both effector T cells and B cell-mediated immunity, preserving T regulatory cell activity; furthermore, blocking the JAK-STAT pathway could reduce interferon signaling, which was overexpressed in patients with MG, particularly when associated with thymomas [39]. Therefore, this new class of drugs could be able to effectively modulate the different pathogenic mechanisms involved in MG [40-42]. Based on the previously exposed report and on the pathogenesis of the disease, we believe JAKi should be considered a safe and well-tolerated therapeutic option to treat patients with concomitant RA and MG, with a low risk of MG exacerbation or worsening. Our study is limited by its retrospective nature, being based on case reports from different centers and settings (rheumatologic, neurologic, internal medicine) characterized by a great degree of heterogeneity either in the neurological or rheumatological disease descriptions and by generally short follow-ups.

\section{Conclusions}

According to our experience and the review of the literature, in patients with active RA and concomitant MG, we consider MTX a valid option as initial DMARD and confirm RTX efficacy as bDMARD. The TNFi role remains uncertain, but we would advise great caution about their use. Eventually, we believe that JAKi should be considered as a reasonable treatment option in such patients.

Author contribution $\mathrm{RB}$ and $\mathrm{AC}$ provided substantial contributions to the conception and design of the work; the analysis and interpretation of data for the work, drafted the work and revised it critically for important intellectual content; gave final approval of the version to be published and agreed to be accountable for all aspects of the work in ensuring that questions related to the accuracy or integrity of any part of the work are appropriately investigated and resolved.

$\mathrm{DB}, \mathrm{FP}$, and EP provided substantial contributions to the acquisition of data for the work; drafted the work and revised it critically for important intellectual content; gave final approval of the version to be published and agreed to be accountable for all aspects of the work in ensuring that questions related to the accuracy or integrity of any part of the work are appropriately investigated and resolved.

MR and OV provided substantial to the analysis and interpretation of data for the work; drafted the work and revised it critically for important intellectual content; gave final approval of the version to be published and agreed to be accountable for all aspects of the work in ensuring that questions related to the accuracy or integrity of any part of the work are appropriately investigated and resolved.

Data availability PRIMA checklist is available as online additional file.

\section{Declarations}

Ethics approval Written informed consent has been obtained from the patient to access and collect data from the medical record to be used in scientific publications.

Consent to participate Written informed consent has been obtained from all the patients to access and collect data from the medical records to be used in scientific publications.

Consent for publication Written informed consent has been obtained from all the patients to access and collect data from the medical records to be used in scientific publications.

Conflict of interest All authors have signed and submitted the Conflict of Interest Disclosure Form according to ICMJE.

Open Access This article is licensed under a Creative Commons Attribution 4.0 International License, which permits use, sharing, adaptation, distribution and reproduction in any medium or format, as long as you give appropriate credit to the original author(s) and the source, provide a link to the Creative Commons licence, and indicate if changes were made. The images or other third party material in this article are included in the article's Creative Commons licence, unless indicated otherwise in a credit line to the material. If material is not included in the article's Creative Commons licence and your intended use is not permitted by statutory regulation or exceeds the permitted use, you will need to obtain permission directly from the copyright holder. To view a copy of this licence, visit http://creativecommons.org/licenses/by/4.0/.

\section{References}

1. Gilhus NE, Tzartos S, Evoli A, Palace J, Burns TM, Verschuuren JJGM (2019) Myasthenia gravis. Nat Rev Dis Primer 5:30. https:// doi.org/10.1038/s41572-019-0079-y

2. Tamer S, Gokce Gunes HN, Gokcal E, Yoldas TK (2016) Coexistence of autoimmune diseases and autoantibodies in patients with myasthenia gravis. Neurol India 64:45-49. https://doi.org/ 10.4103/0028-3886.173638

3. Chang C-C, Lin T-M, Chang Y-S, Chen W-S, Sheu J-J, Chen Y-H, Chen J-H (2019) Thymectomy in patients with myasthenia gravis increases the risk of autoimmune rheumatic diseases: a nationwide cohort study. Rheumatology 58:135-143. https://doi.org/10.1093/ rheumatology/key236

4. Berrih-Aknin S (2014) Myasthenia Gravis: paradox versus paradigm in autoimmunity. J Autoimmun 52:1-28. https://doi.org/10. 1016/j.jaut.2014.05.001

5. Nacu A, Andersen JB, Lisnic V, Owe JF, Gilhus NE (2015) Complicating autoimmune diseases in myasthenia gravis: a review. Autoimmunity 48:362-368. https://doi.org/10.3109/08916934. 2015.1030614

6. Fang F, Sveinsson O, Thormar G, Granqvist M, Askling J, Lundberg IE, Ye W, Hammarström L, Pirskanen R, Piehl F (2015) The autoimmune spectrum of myasthenia gravis: a Swedish population-based study. J Intern Med 277:594-604. https://doi.org/10. 1111/joim. 12310 
7. Mao Z-F, Yang L-X, Mo X-A, Qin C, Lai Y-R, He N-Y, Li T, Hackett ML (2011) Frequency of autoimmune diseases in myasthenia gravis: a systematic review. Int J Neurosci 121:121-129. https://doi.org/10.3109/00207454.2010.539307

8. Misra UK, Kalita J, Singh VK, Kumar S (2020) A study of comorbidities in myasthenia gravis. Acta Neurol Belg 120:59-64. https://doi.org/10.1007/s13760-019-01102-w

9. Incidence and prevalence of myasthenia gravis in rheumatoid arthritis patients with and without treatment compared with the general population. In: ACR Meet. Abstr. https://acrabstracts. org/abstract/incidence-and-prevalence-of-myasthenia-gravis-inrheumatoid-arthritis-patients-with-and-without-treatment-compa red-with-the-general-population/. Accessed 12 Oct 2021

10. Narayanaswami P, Sanders DB, Wolfe G, Benatar M, Cea G, Evoli A, Gilhus NE, Illa I, Kuntz NL, Massey J, Melms A, Murai H, Nicolle M, Palace J, Richman D, Verschuuren J (2021) International consensus guidance for management of myasthenia gravis: 2020 update. Neurology 96:114-122. https://doi.org/10.1212/ WNL.0000000000011124

11. Sanders DB, Wolfe GI, Benatar M, Evoli A, Gilhus NE, Illa I, Kuntz N, Massey JM, Melms A, Murai H, Nicolle M, Palace J, Richman DP, Verschuuren J, Narayanaswami P (2016) International consensus guidance for management of myasthenia gravis: executive summary. Neurology 87:419-425. https://doi.org/10. 1212/WNL.0000000000002790

12. Andonopoulos AP, Terzis E, Tsibri E, Papasteriades CA, Papapetropoulos T (1994) D-penicillamine induced myasthenia gravis in rheumatoid arthritis: an unpredictable common occurrence? Clin Rheumatol 13:586-588. https://doi.org/10.1007/BF02242998

13. Dalakas MC (2019) Immunotherapy in myasthenia gravis in the era of biologics. Nat Rev Neurol 15:113-124. https://doi.org/10. 1038/s41582-018-0110-z

14. El Jammal T, Sève P, Gerfaud-Valentin M, Jamilloux Y (2021) State of the art: approved and emerging JAK inhibitors for rheumatoid arthritis. Expert Opin Pharmacother 22:205-218. https:// doi.org/10.1080/14656566.2020.1822325

15. Melsheimer R, Geldhof A, Apaolaza I, Schaible T (2019) Remicade ${ }^{\circledR}$ (infliximab): 20 years of contributions to science and medicine. Biol Targets Ther 13:139-178. https://doi.org/10.2147/BTT.S207246

16. America TF of the MSAB of the MGF of, Jaretzki A, Barohn RJ, Ernstoff RM, Kaminski HJ, Keesey JC, Penn AS, Sanders DB (2000) Myasthenia gravis: recommendations for clinical research standards. Neurology 55:16-23. https://doi.org/10.1212/WNL.55.1.16

17. Aletaha D, Neogi T, Silman AJ, Funovits J, Felson DT, Bingham CO, Birnbaum NS, Burmester GR, Bykerk VP, Cohen MD, Combe B, Costenbader KH, Dougados M, Emery P, Ferraccioli G, Hazes JMW, Hobbs K, Huizinga TWJ, Kavanaugh A, Kay J, Kvien TK, Laing T, Mease P, Ménard HA, Moreland LW, Naden RL, Pincus T, Smolen JS, Stanislawska-Biernat E, Symmons D, Tak PP, Upchurch KS, Vencovský J, Wolfe F, Hawker G (2010) 2010 Rheumatoid arthritis classification criteria: an American College of Rheumatology/European League Against Rheumatism collaborative initiative. Arthritis Rheum 62:2569-2581. https:// doi.org/10.1002/art.27584

18. Felson DT, Smolen JS, Wells G, Zhang B, van Tuyl LHD, Funovits J, Aletaha D, Allaart CF, Bathon J, Bombardieri S, Brooks P, Brown A, Matucci-Cerinic M, Choi H, Combe B, de Wit M, Dougados M, Emery P, Furst D, Gomez-Reino J, Hawker G, Keystone E, Khanna D, Kirwan J, Kvien TK, Landewé R, Listing J, Michaud K, Martin-Mola E, Montie P, Pincus T, Richards P, Siegel JN, Simon LS, Sokka T, Strand V, Tugwell P, Tyndall A, van der Heijde D, Verstappen S, White B, Wolfe F, Zink A, Boers M (2011) American College of Rheumatology/European League against Rheumatism provisional definition of remission in rheumatoid arthritis for clinical trials. Ann Rheum Dis 70:404-413. https://doi.org/10.1136/ard.2011.149765
19. Angelucci E, Cesarini M, Vernia P (2010) Successful resolution of pneumonia developed in a patient affected by Crohn's disease, rheumatoid arthritis, myasthenia gravis and recurrent uveitis during concomitant treatment with tumour necrosis factor $\alpha$ inhibitors and conventional immunosuppressive drugs. Rheumatol Int 30:977-978. https://doi.org/10.1007/s00296-009-1012-6

20. Oono M, Fujita Y, Uchida N, Kawai U, Fujita-Nakata M, Nakanishi M, Sanada M, Nagayama S, Matsui M (2018) Rheumatoid meningitis developed in patient with stable rheumatoid arthritis and myasthenia gravis-detailed analysis of intracranial inflammation using flow cytometry. J Neuroinflammation 15:151. https://doi.org/10.1186/s12974-018-1196-3

21. Novella-Navarro M, Salvatierra-Ossorio J, Muñoz-Gómez MDM, Pavo-Blanco M (2018) Rheumatoid arthritis and ocular myasthenia gravis: effectiveness of rituximab in the management of these two diseases. Reumatol Clin 14:179-180. https://doi.org/ 10.1016/j.reuma.2017.05.006

22. Horai Y, Honda M, Nishino A, Nakashima Y, Suzuki T, Kawashiri S-Y, Ichinose K, Tamai M, Nakamura H, Motomura M, Origuchi T, Kawakami A (2014) Anti-citrullinated protein antibody-positive rheumatoid arthritis associated with RS3PE syndrome-like symptoms and an elevated serum vascular endothelial growth factor level in a patient with myasthenia gravis. Intern Med Tokyo Jpn 53:895-898. https://doi.org/10.2169/internalmedicine.53. 1897

23. Kerkeni S, Marotte H, Miossec P (2008) Improvement with rituximab in a patient with both rheumatoid arthritis and myasthenia gravis. Muscle Nerve 38:1343-1345. https://doi.org/10.1002/mus.21047

24. Pelechas E, Memi T, Markatseli TE, Voulgari PV, Drosos AA (2020) Adalimumab-induced myasthenia gravis: case-based review. Rheumatol Int 40:1891-1894. https://doi.org/10.1007/ s00296-020-04587-4

25. Fee DB, Kasarskis EJ (2009) Myasthenia gravis associated with etanercept therapy. Muscle Nerve 39:866-870. https://doi.org/10. $1002 /$ mus. 21280

26. Wakata N, Nakazato A, Sugimoto H, Iguchi H, Saito R (2001) A case of myasthenia gravis accompanied by erythema elevatum diutinum and rheumatoid arthritis. J Neurol 248:435-436. https:// doi.org/10.1007/s004150170192

27. Zis P, Argiriadou V, Temperikidis PP, Zikou L, Tzartos SJ, Tavernarakis A (2014) Parkinson's disease associated with myasthenia gravis and rheumatoid arthritis. Neurol Sci 35:797-799. https:// doi.org/10.1007/s10072-014-1660-5

28. Pasnoor M, He J, Herbelin L, Burns TM, Nations S, Bril V, Wang AK, Elsheikh BH, Kissel JT, Saperstein D, Shaibani JA, Jackson C, Swenson A, Howard JF, Goyal N, David W, Wicklund M, Pulley M, Becker M, Mozaffar T, Benatar M, Pazcuzzi R, Simpson E, Rosenfeld J, Dimachkie MM, Statland JM, Barohn $\mathrm{RJ}$, Methotrexate in MG investigators of the muscle study group (2016) A randomized controlled trial of methotrexate for patients with generalized myasthenia gravis. Neurology 87:57-64. https:// doi.org/10.1212/WNL.0000000000002795

29. Smolen JS, Landewé RBM, Bijlsma JWJ, Burmester GR, Dougados M, Kerschbaumer A, McInnes IB, Sepriano A, van Vollenhoven RF, de Wit M, Aletaha D, Aringer M, Askling J, Balsa A, Boers M, den Broeder AA, Buch MH, Buttgereit F, Caporali R, Cardiel MH, Cock DD, Codreanu C, Cutolo M, Edwards CJ, van Eijk-Hustings Y, Emery P, Finckh A, Gossec L, Gottenberg J-E, Hetland ML, Huizinga TWJ, Koloumas M, Li Z, Mariette X, Müller-Ladner U, Mysler EF, da Silva JAP, Poór G, Pope JE, Rubbert-Roth A, Ruyssen-Witrand A, Saag KG, Strangfeld A, Takeuchi T, Voshaar M, Westhovens R, van der Heijde D (2020) EULAR recommendations for the management of rheumatoid arthritis with synthetic and biological disease-modifying antirheumatic drugs: 2019 update. Ann Rheum Dis 79:685-699. https:// doi.org/10.1136/annrheumdis-2019-216655 
30. Rowin J (2008) Etanercept treatment in myasthenia gravis. Ann N Y Acad Sci 1132:300-304. https://doi.org/10.1196/annals.1405. 028

31. Nicocia G, Bonanno C, Lupica A, Toscano A, Rodolico C (2020) Myasthenia gravis after etanercept and ustekinumab treatment for psoriatic arthritis: a case report. Neuromuscul Disord NMD 30:246-249. https://doi.org/10.1016/j.nmd.2020.01.001

32. Bruzzese V, Marrese C, Scolieri P, Hassan C, Lorenzetti R, Zullo A (2015) Myasthenia gravis onset during rheumatic disease: a new paradoxical effect of anti-TNF alpha therapy? Int J Rheum Dis 18:375-376. https://doi.org/10.1111/1756-185X.12340

33. Jonsson DI, Pirskanen R, Piehl F (2017) Beneficial effect of tocilizumab in myasthenia gravis refractory to rituximab. Neuromuscul Disord NMD 27:565-568. https://doi.org/10.1016/j.nmd.2017.03. 007

34. Khokher W, Bhuta S, Kesireddy N, Abuhelwa Z, Mhanna M, Iftikhar S, Horen N, Assaly R (2021) Refractory nivolumabinduced myasthenia gravis treated with abatacept. Am J Ther. https://doi.org/10.1097/MJT.0000000000001405

35. Makarious D, Horwood K (1990) Coward JIG (2017) Myasthenia gravis: an emerging toxicity of immune checkpoint inhibitors. Eur J Cancer Oxf Engl 82:128-136. https://doi.org/10.1016/j.ejca. 2017.05.041

36. Alboini PE, Evoli A, Damato V, Iorio R, Bartoccioni E (2017) Remission of myasthenia gravis with MuSK antibodies during ruxolitinib treatment. Muscle Nerve 55:E12-E13. https://doi.org/ $10.1002 /$ mus. 25458
37. Ajayi S, Becker H, Reinhardt H, Engelhardt M, Zeiser R, von Bubnoff N, Wäsch R (2018) Ruxolitinib. Recent results cancer res fortschritte krebsforsch progres dans rech sur cancer 212:119-132. https://doi.org/10.1007/978-3-319-91439-8_6

38. Ali H, Salhotra A, Modi B, Nakamura R (2020) Ruxolitinib for the treatment of graft-versus-host disease. Expert Rev Clin Immunol 16:347-359. https://doi.org/10.1080/1744666X.2020.1740592

39. Meager A, Wadhwa M, Dilger P, Bird C, Thorpe R, NewsomDavis J, Willcox N (2003) Anti-cytokine autoantibodies in autoimmunity: preponderance of neutralizing autoantibodies against interferon-alpha, interferon-omega and interleukin-12 in patients with thymoma and/or myasthenia gravis. Clin Exp Immunol 132:128-136. https://doi.org/10.1046/j.1365-2249.2003.02113.x

40. Uzawa A, Kuwabara S, Suzuki S, Imai T, Murai H, Ozawa Y, Yasuda M, Nagane Y, Utsugisawa K (2021) Roles of cytokines and $\mathrm{T}$ cells in the pathogenesis of myasthenia gravis. Clin Exp Immunol 203:366-374. https://doi.org/10.1111/cei.13546

41. Behin A, Le Panse R New pathways and therapeutic targets in autoimmune myasthenia gravis. J Neuromuscul Dis 5:265-277. https://doi.org/10.3233/JND-170294

42. Dalakas MC (2012) Biologics and other novel approaches as new therapeutic options in myasthenia gravis: a view to the future. Ann N Y Acad Sci 1274:1-8. https://doi.org/10.1111/j.1749-6632. 2012.06832.x

Publisher's note Springer Nature remains neutral with regard to jurisdictional claims in published maps and institutional affiliations. 